Motoshi I. Kimura $\cdot$ Yasuhiro Kazuki

Akiko Kashiwagi · Yoshiteru Kai · Satoshi Abe

Ottavia Barbieri · Giovanni Levi · Mitsuo Oshimura

\title{
DIx5, the mouse homologue of the human-imprinted DLX5 gene, is biallelically expressed in the mouse brain
}

Received: 18 December 2003/ Accepted: 12 February 2004/Published online: 9 April 2004

(C) The Japan Society of Human Genetics and Springer-Verlag 2004

\begin{abstract}
The mouse Dlx5 gene encodes a distal-lessrelated DNA-binding homeobox protein first expressed during early embryonic development in anterior regions of mouse embryo and is located on chromosome 6, which is the syntenic region to the human chromosome 7q21-q31 imprinting cluster. Recently, its human homologue, DLX5, was identified to be imprinted and maternally expressed, at least in normal human lymphoblasts and in brain tissues. In our study, we analyzed the imprinting status of mouse Dlx 5 by RT-PCR, first in the $\mathrm{F} 1$ of a reciprocal cross between two different mouse strains, and second in heterozygous Dlx5 mutant mice. Both approaches revealed that mouse Dlx5 followed a biallelic pattern of expression in brain tissue and in testis. Our findings suggest that the Dlx 5 gene escapes genomic imprinting, at least in mice of certain genetic backgrounds.
\end{abstract}

M. I. Kimura $\cdot$ Y. Kazuki $\cdot$ Y. Kai $\cdot$ S. Abe $\cdot$ M. Oshimura $(\square)$ Institute of Regenerative Medicine and Biofunction, Graduate School of Medical Science, Tottori University, 86 Nishimachi,

Yonago 683-8503, Japan

E-mail: oshimura@grape.med.tottori-u.ac.jp

Tel.: + 81-859-348260

Fax: $+81-859-348134$

A. Kashiwagi

Laboratory Animal Research Center,

Faculty of Medicine, Tottori University, Yonago, Japan

O. Barbieri

Transgenic Unit, Department of Oncology,

Biology and Genetic, University of Genova,

IST c/o CBA, L.go Rosanna Benzi 10,

16132 Genova, Italy

G. Levi

CNRS UMR5166-MNHN,

Evolution des Regulations Endocriniennes,

7, rue Cuvier, 75231 Paris,

Cedex 05, France
Keywords DLX5 - Dlx5 - Imprinting - Brain - Mouse chromosome $6 \cdot$ Maternally expressed gene

\section{Introduction}

The Dlx5 gene encodes a distal-less-related DNA-binding homeobox protein first expressed during early embryonic development in the anterior region of mouse embryos. In later developmental stages, it appears in the branchial arches, the otic olfactory placodes and their derivatives, restricted regions of the diencephalons and the telencephalon, all extending appendages, and all developing bones (Simeone et al. 1994a,b; Zhao et al. 1994; Ryoo et al. 1997). Homozygous Dlx5 mutant mice exhibit multiple defects in craniofacial structures (Depew et al.1999, Acampora et al. 1999). It has been reported that homozygous Dlx5/Dlx6 double-knockout mice exhibit split hand/foot malformation (SHFM) phenotypes (Merlo et al. 2002). To develop an systematic in vitro approach for the study of human imprinting loci, we have previously generated human monochromosomal hybrids, via microcell chromosome transfer, that contain a single human chromosome of defined parental origin (Kugoh et al. 1999, Meguro et al. 2001). In a recent study, we examined the allelicexpression profiles of 76 ESTs mapped to human chromosome 7q21-q31 using monochromosomal hybrids that contain a human chromosome 7 of defined parental origin. Results revealed that human Dlx5 was preferentially expressed from the maternal allele in normal human lymphocytes and the brain (Okita et al. 2003).

In order to determine whether this imprinting status is conserved in other species, we examined the imprinting status of mouse Dlx5. In our first approach, we took advantage of an intragenic polymorphism within the transcribed region of Dlx 5 and analyzed Dlx 5 mRNA sequences in the $\mathrm{F} 1$ of a reciprocal cross between mouse strains C57BL6/6J (B6) and JF1. As an alternative approach, we used mutant mice that had a portion of their 
Dlx 5 gene replaced with a lacZ reporter gene to generate Dlx $5(+/-)$ or $(-/+)$ mice and examined the imprinting status of this gene.

\section{Materials and methods}

\section{Mouse strains}

For this study, the following mouse strains were used: heterozygous Dlx5 mutant mice wherein Dlx5 exons I and II were replaced with a lacZ gene (see Acampora et al. 1999 for details on targeting) and C57BL6/6J (B6) and JF1 (JF). Reciprocal crosses between B6 and J1 were conducted, and the F1 were used for further experiments. On the other hand, Dlx $5+/-$ and Dlx $5-/$ + mice with a C57B1/6-DBA/2 background were crossed with wt C57BL6/6J. Resulting progeny were again crossed with wild-type C57BL6/6J mice. This process was performed for a total of three generations. Resulting progeny were then used for subsequent studies. All animal experiments were undertaken in compliance with institutional guidelines on animal research.

\section{Primer sequences}

Three primer sets were designed to amplify regions of either the Dlx5 gene or cDNA (NBCI accession number MMU67840). Primer set 1, consisting of F1: 5'GGAGTGTTTGACAGAGTCCCAAGCA-3' and R1: 5'-CGCTTTGCCATAAGAAGCAGAGGTAGGA-3', amplifies a 356-bp region of the $3^{\prime}$-UTR. Primer set 2, consisting of F2: 5'-GGAGTGTTTGACA GAGTCCCAAGCA-3' and R2: 5'-CGCTTTGCCA TAAGAAGCAGAGGTAGGA-3', amplifies a 200-bp portion of exon 1, while primer set 3, F3: 5'-AGCCAGA GGTGAGGATGGTGAATGGTAA-3' and R3: 5'ACCAGATTTTCACCTGTGTTTGCGTCAG-3', generates a 183-bp fragment from exon 2. Primers used to amplify a portion of the Escherichia coli lacZ gene were designated as bgall-F: 5'-GAAGTTCAGATGTG CGGCGAGTTGCGT-3' and bgal2-R: 5'-CCGCA CCTCGCGGAAACCGACATCG CAGGC-3', producing an expected PCR product size of $285 \mathrm{bp}$. As a loading control, a primer pair that amplifies a 723-bp portion of the glyceraldehyde-3-phosphate dehydrogenase (GAPDH) gene, was also designed, with sequences as follows: GAPDH-F: 5'-CCATCTTCCAGGAGCGAGA-3' and GAPDH-R: 5'-TGTCATA CCAGGAAATGAGC- $3^{\prime}$.

Identification of intragenic polymorphism in Dlx5 3'-UTR

Genomic DNA was prepared from both B6 and JF mouse tails by Puregene (Gentra, USA). Using these DNA as templates, a portion of the Dlx5 $3^{\prime}$-UTR was amplified using primers $\mathrm{F} 1$ and $\mathrm{R} 1$. PCR products were directly sequenced using Term Sequence (Amersham Pharmacia, UK) on a LI-COR DNA Sequencer 4200 (ALOKA, Japan). Resulting sequences from B6 and JF were compared to search for polymorphisms in the Dlx5 gene.

\section{RT-PCR}

Total RNA was isolated from various tissues using the AGPC method followed by DNAase (Wako Nippon Gene, Japan) treatment. First strand cDNA synthesis was then performed using an oligo $(\mathrm{dT})_{15}$ primer and MMLV reverse transcriptase (Life Technologies, USA) following manufacturer's recommendations. RT-PCR was then conducted using primers $\mathrm{R} 1$ and $\mathrm{F} 1$ with a step-up protocol detailed as follows: an initial denaturation at $95^{\circ} \mathrm{C}$ for $10 \mathrm{~min}$; three cycles of $95^{\circ} \mathrm{C}$ for $30 \mathrm{~s}$, $60^{\circ} \mathrm{C}$ for $20 \mathrm{~s}$, and $72^{\circ} \mathrm{C}$ for $30 \mathrm{~s}$; three cycles of $95^{\circ} \mathrm{C}$ for $30 \mathrm{~s}, 62^{\circ} \mathrm{C}$ for $20 \mathrm{~s}$, and $72^{\circ} \mathrm{C}$ for $30 \mathrm{~s}$; three cycles of $95^{\circ} \mathrm{C}$ for $30 \mathrm{~s}, 64^{\circ} \mathrm{C}$ for $20 \mathrm{~s}$, and $72^{\circ} \mathrm{C}$ for $30 \mathrm{~s}$; and 20 cycles of $95^{\circ} \mathrm{C}$ for $30 \mathrm{~s}, 66^{\circ} \mathrm{C}$ for $20 \mathrm{~s}, 72^{\circ} \mathrm{C}$ for $30 \mathrm{~s}$, and $72^{\circ} \mathrm{C}$ for $30 \mathrm{~s}$. The RT-PCR conditions used for both primer sets $2(\mathrm{~F} 2 / \mathrm{R} 2)$ and $3(\mathrm{~F} 3 / \mathrm{R} 3)$ are outlined as follows: an initial denaturation at $95^{\circ} \mathrm{C}$ for $2 \mathrm{~min}$; three cycles of $95^{\circ} \mathrm{C}$ for $30 \mathrm{~s}, 60^{\circ} \mathrm{C}$ for $20 \mathrm{~s}$, and $72^{\circ} \mathrm{C}$ for $30 \mathrm{~s}$; three cycles of $95^{\circ} \mathrm{C}$ for $30 \mathrm{~s}, 62^{\circ} \mathrm{C}$ for $20 \mathrm{~s}$, and $72^{\circ} \mathrm{C}$ for $30 \mathrm{~s}$; three cycles of $95^{\circ} \mathrm{C}$ for $30 \mathrm{~s}, 64^{\circ} \mathrm{C}$ for $20 \mathrm{~s}$, and $72^{\circ} \mathrm{C}$ for $30 \mathrm{~s}$; and 20 cycles of $95^{\circ} \mathrm{C}$ for $30 \mathrm{~s}, 66^{\circ} \mathrm{C}$ for $20 \mathrm{~s}, 72^{\circ} \mathrm{C}$ for $30 \mathrm{~s}$, and $72^{\circ} \mathrm{C}$ for $30 \mathrm{~s}$. Optimized conditions to amplify a portion of the lacZ gene using primers bgal1-F and bgal2- $\mathrm{R}$ are specified as follows: an initial denaturation at $95^{\circ} \mathrm{C}$ for $2 \mathrm{~min}$; three cycles of $95^{\circ} \mathrm{C}$ for $30 \mathrm{~s}, 60^{\circ} \mathrm{C}$ for $20 \mathrm{~s}$, and $72^{\circ} \mathrm{C}$ for $1 \mathrm{~min}$; three cycles of $95^{\circ} \mathrm{C}$ for $30 \mathrm{~s}, 62^{\circ} \mathrm{C}$ for $20 \mathrm{~s}$, and $72^{\circ} \mathrm{C}$ for $1 \mathrm{~min}$; three cycles of $95^{\circ} \mathrm{C}$ for $30 \mathrm{~s}, 64^{\circ} \mathrm{C}$ for $20 \mathrm{~s}$, and $72^{\circ} \mathrm{C}$ for $1 \mathrm{~min}$; and 20 cycles of $95^{\circ} \mathrm{C}$ for $30 \mathrm{~s}, 66^{\circ} \mathrm{C}$ for $20 \mathrm{~s}, 72^{\circ} \mathrm{C}$ for $1 \mathrm{~min}$, and $72^{\circ} \mathrm{C}$ for $1 \mathrm{~min}$. All PCR products were analyzed on a $1.2 \%$ agarose gel followed by SYBR Green (Molecular Probes, USA) staining.

\section{Results and discussion}

We initially examined the tissue-specific expression of mouse Dlx 5 by RT-PCR (Fig. 1). Highest transcript levels were observed in the CNS, including the cerebral cortex, hippocampus, olfactory bulb, and diencephalons. Significant transcript levels were also detected in bone marrow, thymus, liver, heart, as well as testis. On the other hand, Dlx 5 transcript was barely detectable in the brain stem and essentially absent in the cerebellum, kidney, spleen, and lung. Our results are consistent with previous reports and are in agreement with the possible role of Dlx5 in early neuronal development.

Our first approach to study the imprinting status of Dlx5 involved searching for interstrain variations in the Dlx5 3'-UTR sequence. We found that B6 mice were 


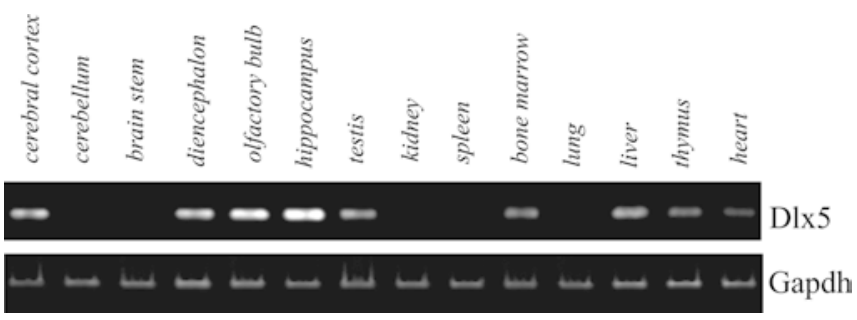

Fig. 1 Tissue-specific expression analysis of mouse Dlx5. Total RNA from the adult mouse was analyzed by RT-PCR using Dlx5specific primers. High transcript levels were observed in brain tissue, suggesting that Dlx5 has significant functions in the CNS. Glyceraldehyde-3-phosphate dehydrogenase (GAPDH) was used as a control

homozygous for the $(\mathrm{T})_{9}$ mononucleotide repeat while $\mathrm{JF}$ mice possessed a $(\mathrm{T})_{13}$ variant in both alleles. The homozygosity of each mouse strain for the corresponding polymorphism as shown by sequencing data (Fig. 2) allowed us to determine the parental origin of the transcribed allele, ultimately enabling us to determine the imprinting status of mouse Dlx5. Should there be a preferential expression of the maternal allele, a JF $\times$ B6 cross should result in progeny exhibiting only the $(\mathrm{T})_{9}$ mononucleotide repeat while a $\mathrm{B} 6 \times \mathrm{JF}$ cross should generate progeny that transcribes only the $(T)_{13}$ allele.

However, this expected pattern was not observed in the progeny of both crosses. Interestingly, direct sequencing of RT-PCR products showed that Dlx5 had a biallelic pattern of expression in the mouse (Fig. 2) in contrast to the previously reported maternal mode of expression in humans.

To confirm this finding, a second approach was attempted to analyze the imprinting status of mouse Dlx5, this time using mutant mice that had exons 1 and 2 replaced with an $E$. coli lac $\mathrm{Z}$ reporter gene to generate a Dlx5 null allele (Fig. 3a). These heterozygous Dlx5 mutant mice were generated by crossing heterozygous Dlx5 mutant C57B1/6-DBA/2 mice with B6 mice for three generations. Based on the recombination frequencies, progeny generated after three generations of crossing would posses an 80-90\% B6 background.

The presence of $\mathrm{Dlx} 5$ and lacZ transcripts was assessed in both Dlx $5+/-$ and $-/+$ mice. To increase the reliability of the results, four primer sets were used for RT-PCR. Three of these primer sets amplify different regions of the Dlx5 transcript, while the fourth primer pair amplifies a portion of the LacZ transcript. All primer sets produced similar RT-PCR profiles in both adult and fetal mouse tissues revealing that Dlx 5 followed a biallelic pattern of expression (Fig. 3b,c), in agreement with the findings from our first approach. Taken together, our results show that mouse Dlx5 gene exhibits a biallelic pattern of expression in all Dlx5-positive tissues examined and further indicates that this gene escapes genomic imprinting, at least in the genetic backgrounds used in our study. This is in contrast to the preferential maternal expression of human Dlx5.
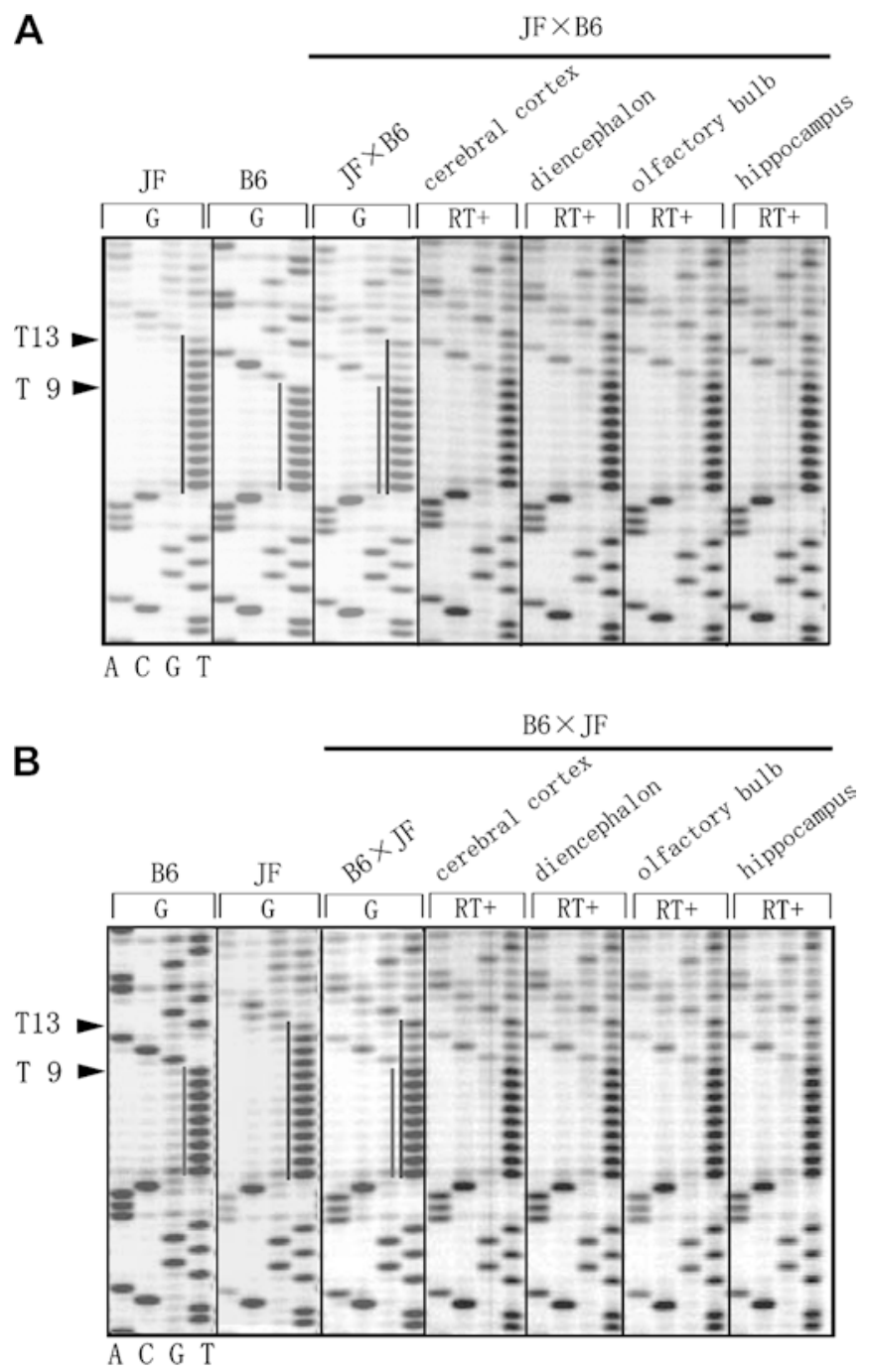

Fig. 2a,b Allele-specific expression analysis of Dlx5 using the reciprocal crosses. a $\mathrm{JF} \times \mathrm{B} 6$, and $\mathbf{b} \mathrm{B} 6 \times \mathrm{JF}$. Direct sequencing of RT-PCR products from the cerebral cortex, diencephalon, olfactory bulb, and hippocampus was performed. Arrowheads show the presence of polymorphic T-nucleotide repeats in the Dlx $53^{\prime}$-UTR. B6 mice were homozygous for the $(\mathrm{T})_{13}$ repeat, while JF mice were homozygous for the $(\mathrm{T})_{9}$ polymorphism. Mouse Dlx 5 follows a biallelic expression pattern. Note the presence of a mixture of both $(\mathrm{T})_{9}$ and $(\mathrm{T})_{13}$ alleles (shorter and longer bars, respectively) in tissue of progeny from reciprocal crosses evidenced by weaker signals of the four topmost T-mononucleotide repeats

A similar discrepancy has also been reported in human and mouse KvLQT1/Kvlqt1. This gene had a maternal pattern of expression in all human fetal tissues expect for the heart. However, in the mouse, this gene exhibited partial relaxation of imprinting in embryonic tissues from male CAST/Ei (CS) $\times$ female 129/SvEv (129) mice and no relaxation of imprinting in embryonic tissues from male CS $\times$ female CS mice (Jiang et al. 1998).

These observations suggest that imprinting patterns may vary among organisms belonging to different species or even strains. Our study provides a new evidence that supports the idea of variation in imprinting patterns 
Fig. 3a-c Imprinting analysis of Dlx 5 in brain tissue and testis from heterozygous Dlx5 null mice. a Targeting strategy used in the generation of a Dlx 5 null allele. Open boxes represent protein-coding sequences, while striped boxes depict noncoding sequences in the Dlx 5 mRNA transcript. Arrowheads indicate annealing sites of PCR primers used in this study. RT-PCR results from b 6-week-old, and c E12.5 Dlx $5+/-$ and $-/+$ mice. Glyceraldehyde-3phosphate dehydrogenase (GAPDH) was used as a control

A Wild-Type Locus

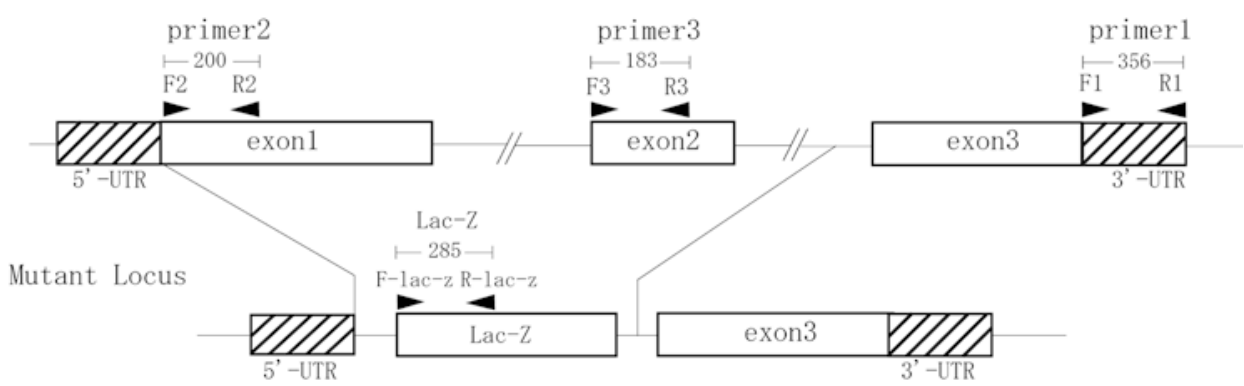

B

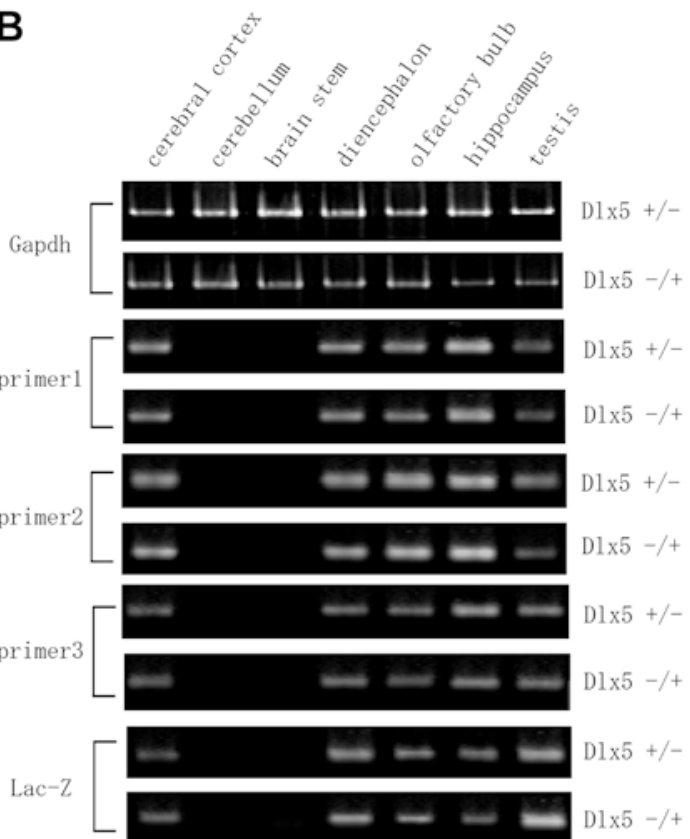

C

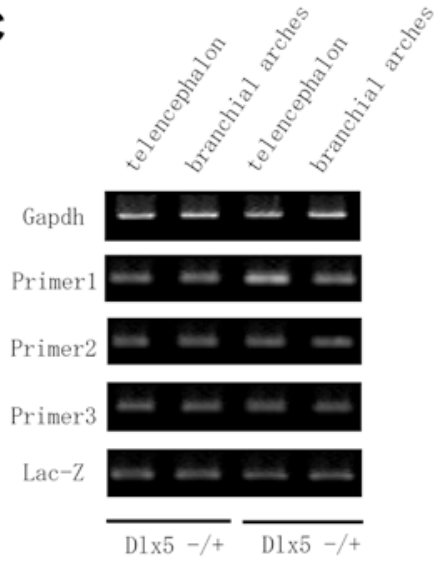

of homologous genes between two species. However, as the experimental design of our study did not provide for the use of pure strains, we are unable to explore the aspect of interstrain differences in the imprinting status of Dlx5. It would be useful to perform more studies using pure mouse strains to examine this possibility.

However, the significance of our findings cannot be overemphasized, as it is one of the first few studies that clearly show the existence of species-species differences in imprinting patterns for homologous genes. Loss or gain of imprinting is known to have tremendous consequences on gene regulation. Why interspecies or even interstrain imprinting differences in some homologous genes cause no apparent disruption of gene regulation in these organisms is a question that would merit further investigation.

Acknowledgements We thank Dr. Haruaki Ninomiya, Dr. Kazuhiko Nakabayashi, and Dr. Akihiro Kurimasa for the valuable discussions and Ms. Candice Ginn T. Tahimic for critical reading and editing of this manuscript. YK is a research fellow of the Japan Society for the Promotion of Science. This study was partly supported by grants from the Ministry of Education, Sports, Science, and Technology and Ministry of Health, Labor, and Welfare of Japan.

\section{References}

Acampora D, Merlo GR, Paleari L, Zerega B, Postiglione MP, Mantero S, Bober E, Barbieri O, Simeone A, Levi G (1999) Craniofacial, vestibular and bone defects in mice lacking the distal-less-related gene Dlx5. Development 126:3795-3809

Depew MJ, Liu JK, Long JE, Presley R, Meneses JJ, Pedersen RA, Rubenstein JL (1999) Dlx5 regulates regional development of the branchial arches and sensory capsules. Development 126:3831-3846

Jiang S, Hemann MA, Lee MP, Feinberg AP (1998) Straindependent developmental relaxation of imprinting of an endogenous mouse gene, Kvlqt1. Genomics 53:395-399

Kugoh H, Mitsuya K, Meguro M, Shigenami K, Schulz TC, Oshimura M (1999) Mouse A9 cells containing single human chromosomes for analysis of genomic imprinting. DNA Res 6:165-172

Meguro M, Kashiwagi A, Mitsuya K, Nakao M, Kondo I, Saitoh S, Oshimura M (2001) A novel maternally expressed gene, ATP10C, encodes a putative aminophospholipid translocase associated with Angelman syndrome. Nat Genet 28:19-20

Merlo GR, Paleari L, Mantero S, Genova F, Beverdam A, Palmisano GL, Barbieri O, Levi G (2002) Mouse model of split hand/foot malformation type I. Genesis 33:97-101

Okita C, Meguro M, Hoshiya H, Haruta M, Sakamoto Y, Oshimura M (2003) A new imprinted cluster on the human chromosome 7q21-q31, identified by human-mouse monochromosomal hybrids. Genomics 81:556-559 
Ryoo HM, Hoffmann HM, Beumer T, Frenkel B, Towler DA, Stein GS, Stein JL, van Wijnen AJ, Lian JB (1997) Stage-specific expression of Dlx-5 during osteoblast differentiation: involvement in regulation of osteocalcin gene expression. Mol Endocrinol 11:1681-1694

Simeone A, Acampora D, Pannese M, D'Esposito M, Stornaiuolo A, Gulisano M, Mallamaci A, Kastury K, Druck T, Huebner K et al (1994a) Cloning and characterization of two members of the vertebrate Dlx gene family. Proc Natl Acad Sci USA 91:2250-2254
Simeone A, D'Apice MR, Nigro V, Casanova J, Graziani F, Acampora D, Avantaggiato V (1994b) Orthopedia, a novel homeobox-containing gene expressed in the developing CNS of both mouse and Drosophila. Neuron 13:83-101

Zhao GQ, Zhao S, Zhou X, Eberspaecher H, Solursh M, de Crombrugghe B (1994) rDlx, a novel distal-less-like homeoprotein is expressed in developing cartilages and discrete neuronal tissues. Dev Biol 164:37-51 